\title{
PENGARUH PENDIDIKAN GIZI DENGAN MEDIA AUDIO KINESTETIK (SENAM DAN LAGU PESAN GIZI SEIMBANG) TERHADAP PENINGKATAN PENGETAHUAN GIZI SEIMBANG PADA ANAK SD MUHAMMADIYAH 4 KANDANGSAPI SURAKARTA
}

\author{
Himaa Aliya $^{1}$, Muwakhidah ${ }^{2}$ \\ ${ }^{1,2}$ Program Studi Ilmu Gizi Fakultas Ilmu Kesehatan Universitas Muhammadiyah \\ Surakarta. Jl. A. Yani, Pabelan, Kartasura, Surakarta. \\ Email: ${ }^{1}$ him.wardoyo@gmail.com, ${ }^{2}$ muwakhidah@ums.ac.id
}

\begin{abstract}
ABSTRAK
SD Muhammadiyah 4 Kandangsapi Surakarta merupakan salah satu sekolah yang masuk dalam persentase pengetahuan kurang yaitu 59\% siswa mempunyai pengetahuan kurang mengenai gizi seimbang. Salah satu upaya yang dapat dilakukan untuk meningkatkan pengetahuan gizi seimbang adalah melalui pendidikan gizi. Tujuan penelitian ini adalah mengetahui pengaruh media audio kinestetik terhadap peningkatan pengetahuan gizi seimbang pada anak SD Muhammadiyah 4 kandangsapi Surakarta. Penelitian ini merupakan penelitian quasy experiment design dengan rencana one group pretestposttest. Pengambilan sampel dengan teknik purposive sampling, jumlah sampel 47 responden. Media yang digunakan dalam penelitian ini berupa media audio kinestetik (senam dan lagu pesan gizi seimbang). Analisis data menggunakan uji Kolmogorof Smirnov dan Uji Wilcoxon sign test. Hasil penelitian menunjukkan bahwa berdasarkan uji Wilcoxon sign test mengenai pengetahuan gizi diperoleh nilai $\mathrm{p}=0.001$, artinya ada pengaruh pendidikan gizi dengan media audio kinestetik terhadap peningkatan pengetahuan siswa. Bagi pihak sekolah sebaiknya media audio kinestetik (senam dan lagu pesan gizi seimbang) dapat diterapkan oleh semua siswa SD Muhammadiyah 4 Kandangsapi Surakarta pada saat melakukan senam pada hari jumat.
\end{abstract}

Kata kunci : Media audio kinestetik, pendidikan gizi, pengetahuan gizi

\begin{abstract}
SD Muhammadiyah 4 Kandangsapi Surakarta is one of the schools with less knowledge, ie 59\% of students have less knowledge about balanced nutrition. One effort that can be done to improve the knowledge of balanced nutrition is through nutrition education. The purpose of the research was to know the influence of kinesthetic audio media to increase knowledge of balanced nutrition in SD Muhammadiyah 4 Kandangsapi Surakarta. The research was a queasy experimental design with one group pretest-posttest plan. The purposive sampling technique was used, with a number of samples
\end{abstract}


was 47 respondents. The media used in the research was kinesthetic audio media (gymnastics and song of balanced nutrition message). Data were analyzed using Kolmogorov-Smirnov test and Wilcoxon test. The results showed that based on Wilcoxon sign test of nutritional knowledge was obtained p-value $=0.001$, meaning there was an influence of nutrition education with kinesthetic audio media to increase student's knowledge. For schools, kinesthetic audio media (gymnastics and balanced nutrition messages) can be applied by all students of SD Muhammadiyah 4 Kandangsapi Surakarta during gymnastics on Friday.

Keywords : Kinesthetic audio media, nutrition education, nutrition balance.

\section{PENDAHULUAN}

Anak sekolah dasar merupakan salah satu kelompok yang rentan terhadap ketidakcukupan gizi, sehingga anak sekolah harus mendapat pemantauan agar ketidakcukupan gizi dapat dihindari (Soediaoetama, 2000). Hasil Riskesdas (2013) menunjukkan secara nasional masalah kegemukan pada anak umur 5-12 tahun sangat tinggi yaitu $18,8 \%$, terdiri dari gemuk $10,8 \%$ dan obesitas $8,8 \%$, prevalensi kurus (menurut IMT/U) pada anak umur 5-12 tahun adalah 11,2\%, terdiri dari $4 \%$ sangat kurus dan $7,2 \%$ kurus.

Masalah gizi yang timbul pada anak usia sekolah dipengaruhi oleh beberapa faktor seperti kebiasaan makan yang buruk, pemahaman gizi yang salah, kesukaan yang berlebihan terhadap satu jenis makanan, promosi yang berlebihan tentang produk makanan di media masa dan maraknya produk makanan impor. Pengetahuan pangan dan gizi juga merupakan salah satu faktor yang mempengaruhi status gizi sehingga diperlukan pendidikan gizi secara formal maupun non formal (Sulistyoningsih, 2012).

Pendidikan tidak terlepas dari proses belajar mengajar. Pendidikan gizi pada anak sekolah dasar harus di dilakukan dengan media yang menarik agar penyampaian materi dapat lebih diterima dengan mudah. Media audio kinestetik (senam dan lagu pesan gizi seimbang) adalah media yang dapat di dengar dengan perantara listrik, bersifat audio dan dapat dipergunakan untuk lagu senam pada anak usia sekolah. Media ini dipilih karena memiliki keunggulan mudah dimengerti, awet, fleksibel, serta bisa dihafal dengan menggunakan gerak dan diiringi lagu untuk menyampaikan pesan gizi seimbang kepada anak usia sekolah.

Gerak dan lagu adalah sarana yang menyenangkan bagi anak untuk senam ataupun berolahraga. Sebab dengan gerak dan lagu anak dapat bergerak sambil mendengarkan musik atau lagu. Kegiatan gerak dan lagu memiliki banyak manfaat. Menurut Kamtini, (2005) beberapa manfaat gerak dan lagu adalah meningkatkan motorik kasar, meningkatkan kreativitas, belajar bersosialisasi dan bekerja sama, melatih kedisiplinan dan melatih konsentrasi anak. Melalui upaya pendidikan gizi dengan media audio kinestetik (senam dan lagu pesan gizi seimbang) ini diharapkan anak usia sekolah dapat meningkatkan pengetahuan tentang gizi seimbang.

Berdasarkan latar belakang diatas, maka perlu diadakan pendidikan gizi pada anak usia sekolah dasar dengan menggunakan media audio kinestetik (senam dan lagu pesan gizi seimbang). 
Penelitian mengenai pengaruh pengetahuan tentang gizi seimbang dengan menggunakan media audio kinestetik (seman dan lagu pesan gizi seimbang) pada anak SD akan dilakukan di SD Muhammadiyah Kandangsapi.

\section{METODE PENELITIAN}

Penelitian ini merupakan penelitian quasy experiment design dengan rencana one group pretest-posttest. Pengambilan sampel dengan teknik purposive sampling, jumlah sampel 47 responden. Media yang digunakan dalam penelitian ini berupa media audio kinestetik (senam dan lagu pesan gizi seimbang). Data kelas dan jenis kelamin diperoleh langsung dari data identitas siswa yang ada di sekolah. Data pengetahuan gizi diperoleh dari pengisian kuesioner secara langsung dikelas sebelum dan sesudah diberi pendidikan gizi. Analisis data menggunakan uji Kolmogorof Smirnov dan Uji Wilcoxon sign test.

\section{HASIL DAN PEMBAHASAN}

\section{Gambaran Umum Lokasi Penelitian Letak Geografis}

SD Muhammadiyah 4 Kandangsapi terletak di kota Surakarta jalan tentara pelajar no 1 Jebres. Letak lokasi SD Muhammadiyah 4 Kandangsapi sangat strategis dan sangat tepat dalam proses belajar mengajar karena jauh dari kebisingan pabrik dan jauh dari kebisingan pasar.

Jumlah siswa di SD Muhammadiyah 4 Kandangsapi saat ini berjumlah 268 siswa yang tersebar di kelas I sampai kelas VI. Jumlah dari masing-masing kelas dapat dilihat pada Tabel 1.
Tabel 1. Distribusi jumlah siswa SD Muhammadiyah 4 Kandangsapi Surakarta 2016/2017

\begin{tabular}{cc}
\hline Kelas & Jumlah siswa \\
\hline I & 45 \\
II & 56 \\
III & 62 \\
IV & 46 \\
V & 20 \\
VI & 39 \\
\hline Total & 268 \\
\hline
\end{tabular}

\section{Karakteristik Sampel Penelitian}

Karakteristik Sampel Berdasarkan kelas

Data karakteristik sampel berdasarkan kelas dapat dilihat pada Tabel 2.

Tabel 2. Karakteristik Sampel Berdasarkan kelas

\begin{tabular}{ccc}
\hline Kelas & Jumlah & Presentase \\
\hline IV & 22 & 46.8 \\
V & 25 & 53.2 \\
\hline Total & 47 & 100 \\
\hline
\end{tabular}

Tabel 2 menunjukan data karakteristik sampel berdasarkan kelas. Dari tabel dapat diketahui bahwa sampel paling banyak ada dikelas $\mathrm{V}$ yaitu 25 siswa $(53,2 \%)$, kemudian pada kelas IV sebanyak 22 siswa $(46,8 \%)$.

Sampel dalam penelitian ini kelas IV dan V dipilih karena ketika siswa kelas IV dan V mudah untuk diajak berkomunikasi dan sudah paham ketika diberi penyuluhan dalam bentuk media.

\section{Karakteristik Sampel Berdasarkan Jenis Kelamin \\ Data karakteristik sampel berdasarkan jenis kelamin dapat dilihat pada Tabel 3.}


Tabel 3. Karakteristik sampel berdasarkan jenis kelamin

\begin{tabular}{lll}
\hline Jenis kelamin & Jumlah & Presentase \\
\hline Laki-laki & 25 & 53.2 \\
Perempuan & 22 & 46.8 \\
\hline Total & 47 & 100 \\
\hline
\end{tabular}

Tabel 3 menunjukan data karakteristik sampel berdasarkan jenis kelamin. Karakteristik sampel berdasarkan jenis kelamin diperoleh sampel terbesar adalah berjenis kelamin laki-laki yaitu 25 siswa $(53.2 \%)$ dan berjenis kelamin perempuan sebanyak 22 siswa (46.8\%).

\section{Karakteristik Sampel Berdasarkan Pengetahuan}

Tingkat pengetahuan sampel diukur dengan menggunakan kuesioner pengetahuan gizi yang berjumlah 21 item pertanyaan yang mencangkup 14 indikator pernyataan. Pengambilan data penelitian dilakukan sebanyak dua kali yang dilakukan sebelum dan setelah diberi pendidikan gizi melalui senam pesan gizi seimbang.

\section{Distribusi Pengetahuan Sampel Sebelum diberi Pendidikan Gizi}

Sebelum dilakukan perlakuan pendidikan gizi dengan media audio kinestetik (senam dan lagu pesan gizi seimbang) sampel terlebih dahulu diberi kuesioner mengenai pengetahuan gizi seimbang. Kuesioner berjumlah 21 item pertanyaan, dalam kuesioner tersebut tidak terdapat pengertian apapun mengenai gizi seimbang hanya ada petunjuk dan langkah pengisian kuesioner.

Pengetahuan sampel sebelum diberi perlakuan pendidikan gizi dengan media audio kinestetik (senam dan lagu pesan gizi seimbang) dapat dilihat pada Tabel 4.
Tabel 4. Distribusi Sampel Berdasarkan Pengetahuan Sebelum diberi Pendidikan Gizi

\begin{tabular}{ccc}
\hline $\begin{array}{c}\text { Pengetahuan } \\
\text { sebelum }\end{array}$ & $\begin{array}{c}\text { Frekuensi } \\
(\mathbf{n})\end{array}$ & $\begin{array}{c}\text { Presentase } \\
(\boldsymbol{\%})\end{array}$ \\
\hline Baik & 19 & $40.42 \%$ \\
Cukup & 19 & $40.42 \%$ \\
Kurang & 9 & $19,16 \%$ \\
\hline Total & 47 & $100 \%$ \\
\hline
\end{tabular}

Hasil penelitian mengenai pengetahuan gizi seimbang sebelum diberi pendidikan gizi dengan media audio kinestetik (senam dan lagu pesan gizi seimbang) dapat dilihat dalam Tabel 4. Tabel 4 menunjukan bahwa 19 sampel atau $40.42 \%$ memiliki pengetahuan gizi seimbang baik dan cukup, sedangkan 9 sampel atau $19,16 \%$ memiliki pengetahuan gizi kurang.

Pertanyaan yang tidak bisa dijawab oleh sampel yaitu pertanyaan nomor 7 mengenai jenis anekaragam makanan sumber karbohidrat sebesar 39 sampel $(82.9 \%)$ jawaban salah, nomor 8 mengenai biasakan konsumsi anekaragam makanan sumber karbohidrat sebesar 25 sampel (53.19\%) jawaban salah, nomor 9 mengenai jenis protein hewani dan protein nabati sebesar 41 sampel $(87.23 \%)$ jawaban salah dan nomor 16 mengenai minum air putih yang cukup dan aman sebesar 27 sampel (57\%) jawaban salah. Hal tersebut dikarenakan pihak sekolah guru dan siswanya sebelumnya belum pernah mendapatkan informasi atau sosialisasi mengenai gizi seimbang.

\section{Distribusi Pengetahuan Sampel Sesudah diberi Pendidikan Gizi}

Pendidikan gizi diberikan dalam bentuk senam dan lagu dalam senam tersebut berupa 10 pesan gizi seimbang serta penjelasan dalam pesan gizi seimbang tersebut. Durasi waktu senam 1 jam setiap satu kelasnya. Awal perlaukan seluruh sampel diberi selembaran yang isinya lirik lagu pesan gizi seimbang, selembaran tersebut diberikan kepada 
seluruh sampel dengan tujuan agar mempermudah sampel dalam menghafal lagu dan latihan gerakan senam. Senam dilakukan secara berkelompok, satu kelompok terdiri dari 5 sampel. Setiap kelompok akan melakukan senam 2 kali dalam satu kali perlakuan. Diharapkan pendidikan gizi dengan media audio kinestetik (senam dan lagu pesan gizi seimbang) dapat memberikan informasi serta meningkatkan pengetahuan sampel mengenai gizi seimbang.

Tabel 5. Distribusi Pengetahuan Sampel Setelah diberi Pendidikan Gizi

\begin{tabular}{ccc}
\hline $\begin{array}{c}\text { Pengetahuan } \\
\text { setelah }\end{array}$ & $\begin{array}{c}\text { Frekuensi } \\
(\mathbf{n})\end{array}$ & $\begin{array}{c}\text { Presentase } \\
(\%)\end{array}$ \\
\hline Baik & 26 & $55,32 \%$ \\
Cukup & 19 & $40,43 \%$ \\
Kurang & 2 & $4,26 \%$ \\
Total & 47 & 100 \\
\hline
\end{tabular}

Hasil penelitian mengenai pengetahuan gizi seimbang setelah diberi pendidikan gizi dengan media audio kinestetik (senam dan lagu pesan gizi seimbang) dapat dilihat dalam Tabel 5. Tabel 5 didapatkan hasil bahwa pengetahuan sampel setelah diberi pendidikan gizi dengan media audio kinestetik (senam dan lagu pesan gizi seimbang) adalah 26 sampel atau 55,32\% sampel mempunyai pengetahuan baik, sedangkan 19 sampel atau 40,43\% sampel memiliki pengetahuan yang cukup dan 2 sampel atau $4,26 \%$ memiliki pengetahuan gizi yang kurang. Hasil tersebut menunjukan bahwa pengetahuan sampel mengalami peningkatan setelah diberi pendidikan gizi. Hal tersebut disebabkan informasi dan pendidikan yang diterima sampel tentang gizi seimbang dapat dipahami dan diserap dengan baik, sehingga pertanyaan dalam kuesioner dapat dijawab dengan benar.

Tabel 6. Distribusi setiap item soal yang benar dan salah dari seluruh jumlah responden berdasarkan indikator pertanyaan yang telah ditentukan

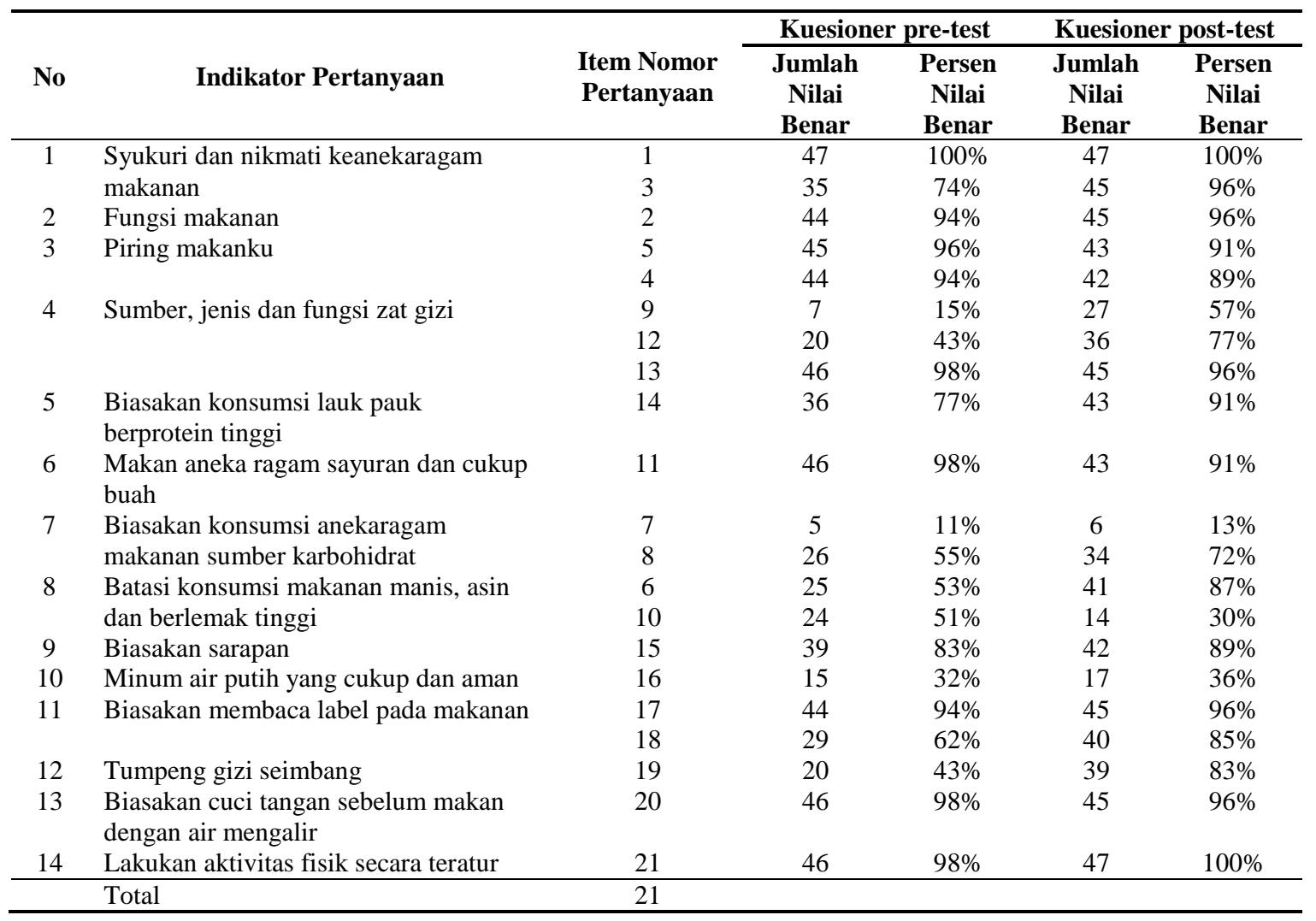


Hasil soal dengan jawaban benar terbanyak pada kuesioner sebelum intervensi dilakukan adalah pada item nomor 1 dan 3 dengan indikator nomor 1 . Hasil soal dengan jawaban benar $<60 \%$ dalam kuesioner sebelum intervensi dilakukan ada pada indikator 4 dengan item soal nomor 9 dan 12 mengenai sumber, jenis dan fungsi zat gizi. Indikator 7 dengan item soal nomor 7 dan 8 mengenai biasakan konsumsi anekaragam makanan sumber karbohidrat, sebagian sampel mengetahui baha makanan yang mengandung karbohidrat hanya nasi tanpa mengetahui bahwa kentang, jagung, gandum dan sejenisnya juga merupakanan makanan sumber karbohidrat. Indikator 8 dengan item soal nomor 6 dan 10 mengenai batasi konsumsi makanan manis, asin dan berlemak tinggi. Indikator 10 dengan item soal nomor 16 mengenai minum air putih yang cukup dan aman dan indikator 12 dengan item soal nomor 19 mengenai tumpeng gizi seimbang.

Hasil sesudah diberi pendidikan gizi ada perubahan untuk hasil nilai benar dan salah pada pre-test dan post-test, tetapi nilai salah masih terbilang tinggi pada post-test meskipun ada penurunan dari sebelum diberi pendidikan gizi dan sesudah diberi pendidikan gizi. Soal dengan jawaban $<60 \%$ setelah diberi pendidikan gizi terdapat pada indikator 4 dengan nomor soal 9, indikator 7 dengan nomor soal 7 , indikator 8 dengan nomor soal 10 dan indikator 10 dengan nomor soal 16 .

Nilai rata-rata pengetahuan responden kelas IV setelah diberi pendidikan gizi sebesar $82 \%$ dan kelas $\mathrm{V}$ sebesar $85 \%$, hal tersebut menunjukan bahwa rata-rata pengetahuan responden kelas IV dan $\mathrm{V}$ mempunyai pengetahuan yang baik mengenai pesan gizi seimbang. Menurut green (1999) pengetahuan dipengaruhi oleh faktor predisposisi, yaitu status ekonomi, umur, jenis kelamin dan susunan dalam keluarga. Berdasarkan teori tersebut umur merupakan salah satu faktor yang mempengaruhi pengetahuan. Umur mempengaruhi daya tangkap dan pola pikir seseorang. Semakian bertambah umur akan semakin berkembang pula daya tangkap dan pola pikirnya, sehingga pengetahuan yang diperolehnya semakin membaik (Notoatmodjo, 2003).

\section{Perbedaan Sebelum dan Sesudah diberi Pendidikan Gizi}

Perbedaan pengetahuan sampel sebelum dan sesudah diberikan pendidikan gizi dengan media audio kinestetik (senam dan lagu pesan gizi seimbang) di SD Muhammadiyah 4 Kandangsapi Surakarta dapat dilihat pada Tabel 7.

Tabel 7. Distribusi Sampel Berdasarkan Pengetahuan Sebelum dan Sesudah diberi Pendidikan Gizi

\begin{tabular}{cccccc}
\hline Pengetahuan & $\mathbf{N}$ & $\begin{array}{c}\text { Nilai } \\
\text { minimum }\end{array}$ & $\begin{array}{c}\text { Nilai } \\
\text { maximum }\end{array}$ & Mean & SD \\
\hline sebelum & 47 & 52.00 & 86.00 & 72.0213 & 10.50981 \\
setelah & 47 & 52.00 & 90.00 & 77.3404 & 8.73841 \\
\hline
\end{tabular}

Hasil penelitian mengenai pengetahuan gizi seimbang sebelum dan sesudah diberi pendidikan gizi dengan media audio kinestetik (senam dan lagu pesan gizi seimbang) dapat dilihat dalam Tabel 7. Tabel 7 menunjukan hasil bahwa pengetahuan sampel sebelum diberi pendidikan gizi dengan media audio kinestetik (senam dan lagu pesan gizi seimbang) nilai rata-ratanya adalah 72.0213, dengan nilai minimum 52.00 dan nilai maksimum 86.00 sedangkan nilai rata-rata sesudah diberi pendidikan gizi dengan media audio kinestetik (senam dan 
lagu pesan gizi seimbang) meningkat menjadi 77.3404 dengan nilai minimum 52.00 dan nilai maksimum 90.00 .

Pengetahuan sampel dalam penelitian ini dibedakan menjadi 3 yaitu pengetahuan baik jika skor nilai jawaban $>80$, pengetahuan cukup jika jawaban benar antara $60 \%-80 \%$ dan pengetahuan kurang jika skor nilai jawaban benar $<60 \%$, jawaban benar diberi skor 1 sedangkan jawaban salah diberi skor 0 Madanijah, (2004). Pertanyaan yang diberikan untuk mengukur pengetahuan sampel berupa kuesioner yang berjumlah 21 item soal. Hasil uji statistik dengan menggunakan uji wilcoxon signed ranks tets diperoleh nilai $\mathrm{p}=0.002$ yang berarti nilai $\mathrm{p}<0.005$ maka Ho di tolak, artinya pada penelitian ini ada pengaruh pengetahuan gizi seimbang sebelum dan sesudah diberi pendidikan gizi dengan media audio kinestetik (senam dan lagu pesan gizi seimbang).

Pengetahuan gizi seimbang pada sampel meningkat sesudah diberi pendidikan gizi. Menurut Notoatmodjo, (2012) pengetahuan merupakan salah satu faktor yang mempengaruhi tindakan seseorang, sehingga jika seseorang mempunyai pengetahuan gizi yang baik maka tindakan dan perilaku seseorang terhadap gizi juga akan baik.

\section{KESIMPULAN}

1. Pengetahuan gizi seimbang siswa di SD Muhammadiyah 4 Kandangsapi Surakarta sebelum dilakukan pendidikan gizi diperoleh kategori baik sebesar $40.42 \%$, kategori cukup sebesar $40.42 \%$ dan kategori kurang sebesar $19.16 \%$.

2. Pengetahuan gizi seimbang siswa di SD Muhammadiyah 4 Kandangsapi Surakarta sesudah dilakukan pendidikan gizi diperoleh nilai dengan kategori baik sebesar $55.32 \%$, nilai dengan kategori cukup sebesar $40.43 \%$ dan nilai dengan kategori kurang sebesar $4.26 \%$.

3. Ada pengaruh sebelum dan sesudah pendidikan gizi seimbang dengan media audio kinestetik (senam dan lagu pesan gizi seimbang) terhadap pengetahuan gizi siswa di SD Muhammadiyah 4 Kandangsapi Surakarta.

\section{DAFTAR PUSTAKA}

Gold, S.R., Green, L., Kreuter, M.W., 1999, Empowering: Enabling Methods of Planning and Organizing within Everyone Reach: Methods Demonstrated in Relation to Early Detection of Breast Cancer, Jones and Bartlett Publisher, London.

Kamtini dan Husni Wardi Tanjung., 2005, Bermain Melalui Gerak dan Lagu Di Taman Kanak-Kanak, Departemen Pendidikan Nasional Direktorat Jenderal Pendidikan Tinggi Direktorat Pembinaan Pendidikan Dan Tenaga Kependidikan Dan Ketenagaan Perguruan Tinggi.

Madanijah, S., 2004, Pendidikan Gizi dalam Pengantar Pengadaan Pangan dan Gizi. Penebar Swadaya. Jakarta.

Notoatmodjo, S., 2003, Pendidikan dan Perilaku Kesehatan, PT. Rineka Cipta, Jakarta. 
Notoatmodjo, S., 2012, Promosi kesehatan dan Perilaku Kesehatan, Rineka cipta, Jakarta.

Riskesdas., 2013, Badan Penelitian Dan Pengembangan Kesehatan Kementerian Kesehatan. Depkes RI. Jakarta

Sediaoetama, A.D., 2000, Ilmu Gizi untuk Mahasiswa dan Profesi Jilid 2, Dian Rakyat, Jakarta.

Sulistyoningsih H., 2012, Gizi untuk Kesehatan Ibu dan anak, Graha Ilmu, Yogyakarta. 